\title{
Editorial: The Eighth Circle
}

In Dante's Inferno the damned are placed in nine descending levels or circles, of ever increasing pain, reflecting the gravity of their sins. So, in the first seven circles, among others, we see the lustful, the gluttons, the avaricious, the angry, the suicidal, the violent, the tyrannical, the proud and the usurious. Then we plunge into a great abyss, at the bottom of which is the eighth circle. In general terms this is the circle of the fraudulent.

In Dante's scheme of things what might be thought of as the straightforward vices of lust, avarice, violence, anger, tyranny and the rest are not absent from the eighth circle. They are indeed there in many forms, but what compounds the sins of those in the eighth circle is that they have fraudulently used their positions of power and status to achieve their ends. Unlike those in the first seven circles, the sins of those in the eighth are compounded by the fraud at the heart of what they do. Jason is there, who used his power to seduce and then betray his lovers; there are flatterers and hypocrites and evil counsellors, there are Popes who use their office for gain (simony) and public officials who enrich themselves (barratry), and there are those who, under a cloak of self-righteous virtue, stir up discord for their own ends.

Dante's animus is directed particularly fiercely at those who use religion to enrich and satisfy themselves. Their crime is that by posing as virtuous and indeed as the ultimate teachers of virtue, they are enabled to pander to their vices. Significantly the simoniac Popes are seen to be close to the Whore of Babylon (a figure who appears again in Purgatorio, this time, and long before Luther, actually representing the Papacy, as it is removing itself to Avignon in the company of the King of France). Dante's solution to ecclesiastical fraudulence is that the Church should be divested of political power and wealth, so that its mission should not be corrupted and positions in it used as means for individuals to achieve their irreligious ambitions.

Our situation is not so different from what it was in the fourteenth century, when Dante wrote. Influential men abuse their power over women; priests are revealed as paedophiles; charity workers sexually exploit those they are supposed to be helping; education becomes a means by which top officials disproportionately enrich themselves; public discourse is dominated by discord at the expense of understanding. In many of these cases what particularly compounds the 


\section{Editorial}

offence is the way that noble ends and supposedly altruistic institutions are subverted. The institutions in question thus become prey to those who see them as vehicles to further their own selfish and ignoble ends - which is why Dante particularly excoriated the Papacy of his day.

In retrospect his solution - separation of the roles of Church and State - might seem naïve. The power of clergy over vulnerable individuals does not arise primarily from the worldly power of their churches, but rather from the trust their position affords them. For our part, in 2018 we can - and do - institute committees of enquiry and submerge institutions with regulation, once fraudulence is revealed. But, necessary as these measures may be, no more than with Dante's solution should we think that inquiry and regulation will put an end to fraudulent activity. As we see from the eighth circle, it is of the nature of human beings to deceive others, and themselves; and never is fraud more insidious when it is masquerading as virtue and corrupting the best of institutions. 